\title{
Türkiye'de 2019 Yılı İçinde İzole Edilen Escherichia coli ve Klebsiella pneumoniae İzolatlarında Karbapenemaz Epidemiyolojisi
}

\section{The Epidemiology of Carbapenemases in Escherichia coli and Klebsiella pneumoniae Isolated in 2019 in Turkey}

\author{
Serap SÜZÜK YILDIZ1 (ID), Hüsniye ŞiMŞEK'(ID), Zekiye BAKKALOĞLU ${ }^{1}(I D)$,

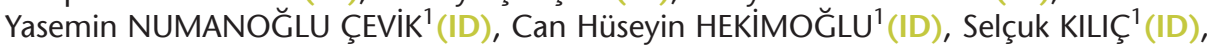 \\ Emine ALP MEŞE²(ID), Ulusal Karbapenemaz Sürveyans Çalışma Grubu* \\ 1 Sağlık Bakanlığı, Halk Sağlığı Genel Müdürlüğü, Mikrobiyoloji Referans Laboratuvarı ve Biyolojik Ürünler Daire \\ Başkanlığı, Ankara. \\ ${ }^{1}$ Ministry of Health General Directorate of Public Health, Department of Microbiology Reference Laboratory and Biological \\ Products, Ankara, Turkey. \\ 2 Sağlık Bakanlığı, Ankara \\ ${ }^{2}$ Ministry of Health Ankara, Turkey.
}

* Ulusal Karbapenemaz Sürveyans Çalışma Grubu (isme göre alfabetik olarak sıralanmıştır.) Alper Akçalı(ID), Ayşe Ulusoy Karaca(ID), Banu Bayraktar(ID), Canan Eryıldız(ID), Cem Çelik(ID), Devrim Dündar(ID), Ebru Evren(ID), Eda Demirkan(ID), Esra Özkaya(ID), Fatma Bağcı(ID), Fikriye Milleti Sezgin(ID), Filiz Kibar(ID), Hatice Türk Dağı(ID), Hüseyin Güdücüoğlu(ID), İpek Mumcuoğlu(ID), Mahmut Celalettin Üner(ID), Melahat Gürbüz(ID), Murat Telli(ID), Mustafa Zahir Bakıcı(ID), Nergis Aşgın(ID), Osman Sezer Cirit(ID), Pervin Özlem Balcı(ID), Rıza Adaleti(ID), Sebahat Aksaray(ID), Senem Akgül(ID), Şöhret Aydemir(ID), Yeşim Çekin(ID), Yücel Duman(ID), Zeynep Ceren Karahan(ID).

Makale Atıfı: Süzük Yıldız S, Şimşek H, Bakkaloğlu Z, Numanoğlu Çevik Y, Hekimoğlu CH, Kılıç S ve ark. Türkiye'de 2019 yılı içinde izole edilen Escherichia coli ve Klebsiella pneumoniae izolatlarında karbapenemaz epidemiyolojisi. Mikrobiyol Bul $2021 ; 55(1): 1-16$.

\section{Öz}

Antibiyotiklere direnç dünyanın en önemli halk sağlığı sorunlarından biri olup, direncin önlenmesindeki kritik basamaklardan biri direncin izlenmesidir. İzlemin yerel, bölgesel ve küresel olması yayılımın daha net anlaşılmasına olanak sağlamaktadır. Bu çalışmada Escherichia coli ve Klebsiella pneumoniae izolatlarında moleküler tabanlı pilot karbapenem direnci sürveyans sisteminden elde edilen verilere göre ülke genelinde karbapenemaz epidemiyolojisinin belirlenmesi amaçlanmıştır. Türkiye'nin 26 istatistiki düzey-II bölgesinden 28 hastane çalışmaya dahil edilmiştir. Çalışmaya dahil edilen hastaneler 1 Mart-31 Ağustos 2019 ya da 1 Nisan-30 Eylül 2019 tarihleri arasında altı aylık dönemde klinik örneklerden izole edilen 10 adet karbapenem duyarlı, 10 adet karbapenem dirençli E.coli ve K.pneumoniae izolatını laboratuvarımıza göndermiştir. Çalışmaya katılan 28 hastanenin 26 tanesinden toplam 509 izolat gönderilmiştir. İzolatlar matriks aracılı lazer desorpsiyon iyonizasyon uçuş süresi kütle spektrometrisi ["matrix assisted laser desorptionization-time of flight mass spectrophotometry" (MALDI-TOF MS)] (Bruker Daltonics, Almanya) yöntemi ile tanımlanmış ve imipenem, meropenem ve kolistin duyarlılıkları sıvı mikrodilüsyon ile amikasin, amoksisilin klavulonik asit, ampisilin, aztreonam, sefepim, sefotaksim, seftazidim, siprofloksasin, ertapenem, gentamisin, piperasilin-tazobaktam, tobramisin ve trimetoprim sülfametoksazol duyarlılıkları 
disk difüzyon ile çalışılmıştır. Karbapenem ve/veya kolistine fenotipik olarak dirençli bulunan izolatlarda karbapenemaz direnç genleri in house polimeraz zincir reaksiyonu (PCR) yöntemi ile ve mcr 1-8 direnç genleri kolistin direnci gerçek zamanlı PCR kiti (Bio-Speedy, Türkiye) ile araştırılmıştır. Hastanelerden toplanan 509 izolatın 493'ü tür düzeyinde E.coli $(\% 25.7, \mathrm{n}=127)$ ve K.pneumoniae $(\% 74.3, \mathrm{n}=366)$ olarak tanımlanmış ve çalışmaya dahil edilmiştir. Değerlendirilen izolatların \%31'inin toplum kökenli enfeksiyon etkeni, \%69'unun ise sağlık hizmetleri ile ilişkili enfeksiyon etkeni ya da kolonize olan bakteri olduğu tespit edilmiştir. İzolatların 248 (\%50.3)'i karbapenemlere duyarlı, 245 (\%49.7)'i karbapenemlere dirençli olarak belirlenmiştir. Karbapenemlerden en az birine dirençli olan izolatlarda tespit edilen karbapenemaz türleri OXA-48 (\%52.2), KPC (\%16.1), NDM-1 (\%15), OXA-48 + NDM-1 (\%12.6), KPC + NDM-1 (\%2.8) ve birer izolatta VIM (\%0.5) ve OXA-48 + VIM (0.5) belirlenmiştir. İzolatların \%23.3'ünde kolistin direnci tespit edilmiş olup mcr 1-8 genleri tespit edilememiştir. Kolistine dirençli izolatların tümünün en az bir karbapeneme dirençli olduğu görülmüştür. Ülkemizde moleküler tabanlı antibiyotik direnç sürveyans sisteminin önemi bu pilot çalışma ile ortaya konmuştur. Bu epidemiyolojik özelliklerin sürekli takip edilmesinin karbapenemaz direncinin yönetimine katkı sağlayacağı düşünülmüştür.

Anahtar kelimeler: Karbapenemez; sürveyans sistemi; K.pneumoniae; E.coli.

\section{ABSTRACT}

Antibiotic resistance is one of the most important public health problem and one of the most critical steps in preventing resistance is the monitorization of the resistance. Local, regional and global monitoring enables the spread of antibiotic resistance to be understood more clearly. In this study, it was aimed to evaluate the results of the pilot study for the establishment of molecular-based carbapenem surveillance system in Escherichia coli and Klebsiella pneumoniae isolates and to investigate the carbapenemase epidemiology in Turkey. Hospitals $(n=28)$ from 26 different statistical level II regions from Turkey were included in the study. The hospitals participated in the study submitted ten carbapenem susceptible and ten carbapenem resistant E.coli and K.pneumoniae isolates to our laboratory that were isolated in two different periiods of six-month either between 1 March-31 August or 1 April-30 September 2019. A total of 509 isolates were collected from 26 of the 28 participating hospitals in the study. Isolates were identified by matrix assisted laser desorptionization-time of flight mass spectrophotometry (MALDI TOF MS) (Bruker Daltonics, Germany) method and antibiotic susceptibility tests for imipenem, meropenem and colistin were studied by broth microdilution. Moreover, susceptibilities to amikacin, amoxicillin-clavulanic acid, ampicillin, aztreonam, cefepime, cefotaxime, ceftazidime, ciprofloxacin, ertapenem, gentamicin, piperacillin-tazobactam, tobramycin and trimethoprim-sulfamethoxazole were determined by disc diffusion method. The resistance genes were investigated in isolates which were found to be phenotypically resistant to carbapenem and colistin, in house method was used to investigate carbapenemase genes and a commercial colistin resistant real-time PCR kit (Biospeedy, Turkey) was used for colistin resistance genes. In total, 493 of the 509 isolates collected from hospitals were identified as E.coli $(25.7 \%, \mathrm{n}=127)$ and K.pneumoniae $(74.3 \%, \mathrm{n}=366)$ and included in the study. It was determined that $31 \%$ of the isolates evaluated were from community-acquired infections and $69 \%$ were either from healthcare-associated infections or from colonization sites. Among the tested isolates, 248 (50.3\%) were susceptible to carbapenems and 245 (49.7\%) were resistant. The types of carbapenemases in carbapenemase-producing isolates were OXA-48 (52.2\%), KPC (16.1\%), NDM-1 (15\%), OXA-48 + NDM-1 (12.6\%), KPC + NDM-1 $(2.8 \%)$ and VIM $(0.5 \%)$ and OXA-48+VIM (0.5\%). Resistance to colistin was detected in $23.3 \%$ of the isolates but $m c r 1-8$ genes were not detected. It was found that all colistin resistant isolates are resistant to at least one of the carbapenems. The importance of a molecular-based antimicrobial resistance surveillance system in our country was demonstrated with this pilot study. It is thought that continuous monitoring of these epidemiological features will contribute to the management of infections due to carbapenemase-producing organisms.

Keywords: Carbapenemase; surveillance system; K.pneumoniae; E.coli.

\section{Giriş̧}

Dünya Sağlık Örgütü (DSÖ), antibiyotik direncini toplum genelinde eylem gerektiren ve küresel sağlık güvenliğini tehdit eden bir sorun olarak tanımlamaktadır. Örgütün 2014 
yılında hazırladığı rapora göre üye ülkelerin tümünde, özellikle son yıllarda Escherichia coli ve Klebsiella pneumoniae gibi bakterilerde direnç sorunu ciddi boyutlara ulaşmaktadır ${ }^{1}$. Bunun en önemli nedenlerden biri de özellikle son yıllarda genişlemiş spektrumlu beta-laktamaz üreten Enterobacterales izolatlarına karşı karbapenemlerin yoğun bir şekilde kullanılmasıdır². Mevcut sürveyans sistemlerinin bazı eksiklikleri olmakla birlikte, dünya genelinde direnç varlığını ve eğilimlerini ortaya koymada en etkili yöntem sürveyans sistemleridir, ayrıca direncin önlenmesi ve kontrolündeki en önemli basamaklardan biri de sürveyans sistemleridir ${ }^{3}$. Ülkelerin ulusal bazda ulusal sürveyanslarının yanı sıra bölgesel ve hatta küresel sürveyans sistemlerinin oluşturulması yönünde Dünya Sağlık Örgütü (DSÖ)’nün önerisi bulunmaktadır ${ }^{4}$. Ülkemizde de 2011 yılından beri kan kültürü ve beyin omurilik sıvısı örneklerinden izole edilen bakterilerin ve direnç oranlarının izlendiği Ulusal Antimikrobiyal Direnç Sürveyans Sistemi (UAMDSS) mevcuttur. UAMDSS, DSÖ Avrupa Ofisi tarafından yürütülen ve aynı metodolojinin kullanıldığı bir bölgesel sürveyans sistemi olan Orta Asya ve Avrupa Antimikrobiyal Direnç Sürveyans (Central Asian and European Surveillance of Antimicrobial Resistance, CAESAR) ağına dahildir ${ }^{5}$. Bölgesel hatta küresel sürveyans sistemleri antibiyotik direncinin tüm dünyada ortak bir pencereden izlenmesine de olanak sağlamaktadır.

Avrupa Birliğine üye ve aday olan tüm ülkelerde karbapenem ve/veya kolistin dirençli E.coli ve K.pneumoniae klonlarının sağlık hizmeti sunumunda ortaya çıkışı ve coğrafi dağılımını ortaya koymak için Avrupa Hastalıkları Önleme ve Kontrol Merkezi [European Centre for Disease Prevention and Control (ECDC)] tarafından tüm genom analizine dayalı pilot bir sürveyans çalışması başlatılmıştır ${ }^{6}$. Bu çalışmada hem ülkelerin genomik bazlı sürveyans sistemi kurması yönünde bir kapasite çalışılması hem de karbapenem ve/veya kolistine dirençli izolatların Avrupa Bölgesinde yayılımlarının ve risk değerlendirmelerinin yapılması amaçlanmıştır. Bu amaçla, 2017 yılında ECDC önderliğinde Avrupa Birliğine üye ve aday ülkelerde moleküler tüm genom analizine dayalı Avrupa Antibiyotik Direnç Genleri Sürveyans Ağı [European Antimicrobial Resistance Genes Surveillance Network (EURGen-Net)] kurulmuş ve Türkiye de bu ağa katılmak üzere davet edilmiştir 6 . Proje kapsamında ülke genelinde pilot bir moleküler tabanlı sürveyans sistemi oluşturulmuştur. Bu çalışmada, hem ülkelerin genomik temelli sürveyans sistemi kurması yönünde bir kapasite geliştirme çalışması yapılması hem de karbapenem ve/veya kolistine dirençli izolatların Avrupa Bölgesinde yayılımlarının ve risk değerlendirmelerinin saptanması amaçlanmıştır.

\section{GEREÇ ve YÖNTEM}

Bu çalışma, T.C. Sağlık Bakanlığı Halk Sağlığı Genel Müdürlüğünün onayı ile gerçekleştirildi (Tarih: 08.10.2020 ve Karar no: 80962070).

\section{EURGen-Net Projesi}

Proje ECDC, İsveç Halk Sağlığı Enstitüsü ve Sanger Enstitüsü tarafından oluşturulan bir konsorsiyum önderliğinde yürütülmektedir. Avrupa Birliğine üye ve aday bölgelerin tümünü içerecek şekilde ülkeler davet edilmiştir. Davet edilen her ülkenin düzey-II ista- 
tistiki bölgelerinde yer alan en az bir hastanenin programa dahil edilmesi planlanmıştır. Her bir katılımcı hastanenin, klinik örneklerden izole edilmiş 10 adet karbapenemlere (imipenem, meropenem ve ertapenemin her üçüne de) duyarlı, 10 adet karbapenemlerden (imipenem, meropenem veya ertapenem) en az birine dirençli ve/veya kolistine dirençli E.coli veya K.pneumoniae izolatı göndermesi istenmiştir. Örneklerin toplanması için her katılımcı hastaneye kendi uygunluklarına göre seçebilecekleri iki farklı 6 aylık dönem belirlenmiştir. İzolatların tanımlanmaları ve antibiyotik duyarlılık testleri referans merkezde çalışılacak ve izolatlar daha sonra tüm genom analizi için Sanger Enstitüsüne gönderilecektir 6 .

\section{Hastanelerin Belirlenmesi}

Hastaneler, Türkiye'nin düzey-II istatistiki bölgelerinden seçilmiştir. Seçilen hastaneler için bakanlık onayı alındı ve hastane yönetimine resmi yazı ile seçildiklerine dair ve sürveyans çalışması hakkında bilgilendirme yapıldı. Sürveyans çalışmasının tanıtımı ve işleyişi ile ilgili bir standart uygulama prosedürü hazırlandı ve katılımcı hastaneler ile paylaşıldı. Seçilen toplam 28 hastane ve bu hastanelerden toplanan E.coli ve K.pneumoniae izolat sayıları Tablo I'de yer almaktadır.

\section{Epidemiyolojik ve Klinik Verilerin Toplanması}

Belirlenen hastanelerden 01 Mart-31 Ağustos 2019 ya da 1 Nisan-30 Eylül 2019 tarihleri arasında her bir izolatın farklı hastalardan izole edilmesi koşuluyla ertapenem, meropenem ve imipenem antibiyotiklerinin tümüne duyarlı on adet ve bu sayılan karbapenem grubu antibiyotiklerden en az birine dirençli olarak saptanan on adet aynı türde izolat göndermeleri istendi. İzolatlara ve izole edildikleri hastaya ait klinik ve epidemiyolojik veriler toplandı. Toplanan klinik, epidemiyolojik ve mikrobiyolojik veriler Tablo II'de yer almaktadır.

\section{İzolatların Toplanması}

Toplam 509 izolat taşıma besiyeri ile hastaneler tarafından Sağlık Bakanlığı Halk Sağlığı Mikrobiyoloji Referans Laboratuvarları ve Biyolojik Ürünler Daire Başkanlığına gönderildi. Taşıma besiyerinde gelen örneklerin \%5'lik koyun kanlı agara ekimleri yapıldı. Bir gecelik inkübasyondan sonra izolatlar, antibiyotik duyarlıık testleri ve moleküler testler uygulanıncaya kadar \%15 gliserol (Merck, Almanya) içeren triptik soy buyyon besiyerinde (Fluka, 22092, ABD) $-80^{\circ} \mathrm{C}^{\prime}$ de saklandı.

\section{İzolatların Tanımlanması ve Antibiyotik Duyarlılık Testleri}

Çalışmaya dahil edilen izolatlar stoklardan çıkarılarak \%5 koyun kanlı agarda pasajlandı. Bakteriler MALDI TOF MS (Bruker Daltonics, Almanya) ile üretici firma önerileri doğrultusunda tür düzeyinde tanımlandı. E.coli ve K.pneumoniae olarak tanımlanan izolatların amikasin (30 $\mu \mathrm{g})$, amoksisilin klavulonik asit (20-10 $\mu \mathrm{g})$, ampisilin (10 $\mu \mathrm{g})$, aztreonam $(30 \mu \mathrm{g})$, sefepim $(30 \mu \mathrm{g})$, sefotaksim $(5 \mu \mathrm{g})$, seftazidim $(10 \mu \mathrm{g})$, siprofloksasin $(5 \mu \mathrm{g})$, ertapenem $(10 \mu \mathrm{g})$, gentamisin $(10 \mu \mathrm{g})$, piperasilin tazobaktam $(30-6 \mu \mathrm{g})$, tobramisin 
Tablo I. Çalışmaya Katılan Hastanelerin $(n=28)$ istatistiki Bölgelere Göre Dağılımı ve Hastanelerden Gönderilen izolat Sayıları

\begin{tabular}{|c|c|c|c|c|}
\hline Hastane Adı & NUTS-2* Bölgesi & E.coli & K.pneumoniae & Toplam \\
\hline Haydarpaşa Eğitim Araştırma Hastanesi & TR10 & 2 & 18 & 20 \\
\hline $\begin{array}{l}\text { Şişli Hamidiye Etfal Eğitim ve Araştırma } \\
\text { Hastanesi }\end{array}$ & TR10 & 4 & 16 & 20 \\
\hline Ankara Numune Eğitim ve Araştırma Hastanesi & TR51 & 10 & 8 & 18 \\
\hline $\begin{array}{l}\text { Ankara Üniversitesi Tıp Fakültesi, İbn-i Sina } \\
\text { Hastanesi }\end{array}$ & TR51 & 0 & 19 & 19 \\
\hline Selçuk Üniversitesi Tıp Fakültesi Hastanesi & TR52 & 1 & 19 & 20 \\
\hline $\begin{array}{l}\text { Bursa Şevket Yılmaz Eğitim ve Araştırma } \\
\text { Hastanesi }\end{array}$ & TR41 & 3 & 16 & 19 \\
\hline Kocaeli Üniversitesi Tıp Fakültesi Hastanesi & TR42 & 0 & 19 & 19 \\
\hline Ege Üniversitesi Tıp Fakültesi Hastanesi & TR31 & 4 & 10 & 14 \\
\hline $\begin{array}{l}\text { Adnan Menderes Üniversitesi Tıp Fakültesi } \\
\text { Hastanesi }\end{array}$ & TR32 & 0 & 20 & 20 \\
\hline Manisa Devlet Hastanesi & TR33 & 10 & 9 & 19 \\
\hline Trakya Üniversitesi Tıp Fakültesi Hastanesi & TR21 & 9 & 10 & 19 \\
\hline $\begin{array}{l}\text { Onsekiz Mart Üniversitesi Tıp Fakültesi } \\
\text { Hastanesi }\end{array}$ & TR22 & 10 & 10 & 20 \\
\hline Antalya Eğitim ve Araştırma Hastanesi & TR61 & 8 & 10 & 18 \\
\hline Çukurova Üniversitesi Tıp Fakültesi Hastanesi & TR62 & 0 & 19 & 19 \\
\hline Hatay Antakya Devlet Hastanesi & TR63 & 6 & 14 & 20 \\
\hline Karabük Üniversitesi Tıp Fakültesi Hastanesi & TR81 & 1 & 19 & 20 \\
\hline Kastamonu Münif İslamoğlu Devlet Hastanesi & TR82 & 4 & 16 & 20 \\
\hline Tokat Devlet Hastanesi & TR83 & 10 & 6 & 16 \\
\hline Ahi Evran Üniversitesi Tıp Fakültesi Hastanesi & TR71 & 0 & 20 & 20 \\
\hline Cumhuriyet Üniversitesi Tıp Fakültesi Hastanesi & TR72 & 6 & 14 & 20 \\
\hline KTÜ Tıp Fakültesi Hastanesi & TR90 & 6 & 13 & 19 \\
\hline $\begin{array}{l}\text { Gaziantep Ersin Arslan Eğitim ve Araştırma } \\
\text { Hastanesi }\end{array}$ & TRC1 & 10 & 6 & 16 \\
\hline $\begin{array}{l}\text { Şanlıurfa Mehmet Akif İnan Eğitim ve } \\
\text { Araştırma Hastanesi }\end{array}$ & TRC2 & & & \\
\hline Mardin Devlet Hastanesi & TRC3 & 6 & 13 & 19 \\
\hline $\begin{array}{l}\text { İnönü Üniversitesi Tıp Fakültesi Turgut Özal } \\
\text { Hastanesi }\end{array}$ & TRB1 & 2 & 18 & 20 \\
\hline $\begin{array}{l}\text { Van 100. Yıl Üniversitesi Tıp Fakültesi } \\
\text { Hastanesi }\end{array}$ & TRB1 & 8 & 12 & 20 \\
\hline Erzurum Bölge Eğitim ve Araştırma Hastanesi & TRA1 & 7 & 12 & 19 \\
\hline Kars Harakani Devlet Hastanesi & TRA2 & & & \\
\hline Toplam & & 127 & 366 & 493 \\
\hline
\end{tabular}




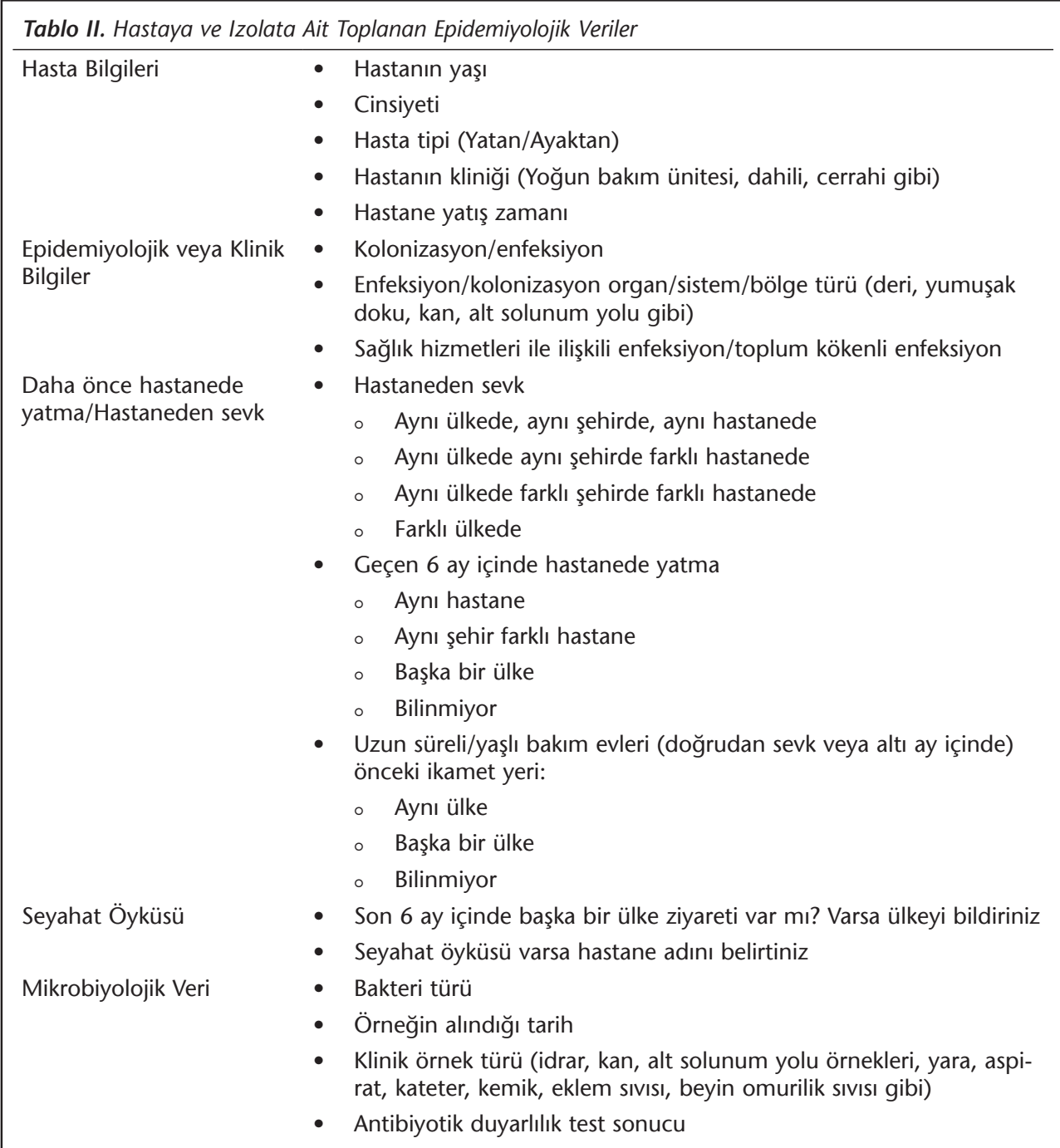

$(10 \mu \mathrm{g})$, trimetoprim sülfametoksazol (1,25-23,75 $\mu \mathrm{g})$ (Oxoid, Birleşik Krallık) antibiyotik duyarlııkları disk difüzyon yöntemi ile imipenem, meropenem ve kolistin (Sigma-Aldrich, St. Louis, MO) duyarılık testleri sıvı mikrodilüsyon yöntemi ile çalışıldı ve tüm sonuçlar "European Committee on Antimicrobial Susceptibility Testing (EUCAST)" kriterlerine göre değerlendirildi ${ }^{7}$. Sıvı mikrodilüsyon yöntemi ile tüm antibiyotikler $0.125-128 \mathrm{mg} / \mathrm{L}$ konsantrasyon aralığında çalışılarak MiK belirlendi ve istatistiksel analiz $\mathrm{t}$ test ile yapıldı. Antibiyotik duyarılıık testlerinin çalışılmasında kalite kontrolü amacıyla Escherichia coli ATCC 25922 ve Escherichia coli NCTC 13846 suşları kullanıldı. 


\section{Karbapenemaz ve $\mathrm{mcr}$ Direnç Genlerinin Belirlenmesi}

En az bir karbapeneme dirençli bulunan izolatlarda, dirençten sorumlu olabilecek genlerin belirlenmesi için PCR yöntemi uygulandı. EURGen-NET protokolüne göre belirlenmiş olan ve ülkemizde yaygın olarak görülen sekiz karbapenemaz geni ( $b / a_{\mathrm{OXA}-23^{\prime}} b / a_{\mathrm{O}}$ ${\mathrm{XA}-48^{\prime}}$ bla $a_{\mathrm{OXA}-51^{\prime}}, b l a_{\mathrm{OXA}-58^{\prime}}, b / a_{\mathrm{NDM}-1}, b / a_{\mathrm{IMP}}, b / a_{\mathrm{VIM}^{\prime}}$ ve $\left.b / a_{\mathrm{KPC}}\right)$ çalışıldı. İzolatlarda bla ${ }_{\mathrm{OXA}-23}$ geni varlığı için F(5'-GAT CGG ATT GGA GAA CCA GA-3') ve R (5'- ATT TCT GAC CGC ATT TCC AT-3'), bla ${ }_{\text {OXA-48 }}$ geni varlığı için F (5'- TTG GTG GCA TCG ATT ATC GG-3') ve R (5'- GAG CAC TTC TTT TGT GAT GGC-3'), bla ${ }_{\text {OXA-51 }}$ geni varlığı için F (5'-TAA TCC TTT GAT CGG CCT TG-3') ve R (5' - TGG ATT GCA CTT CAT CTT GG-3'), bla ${ }_{\text {OXA-58 }}$ geni varlığı için F (5' - AAG TAT TGG GGC TTG TGC TG-3') ve R (5'- CCC CTC TGC GCT CTA CAT AC$\left.3^{\prime}\right)$, bla ${ }_{\mathrm{NDM}-1} \mathrm{~F}$ geni varlığı için (5'- GTA GTG CTC AGT GTC GGC AT-3') R (5'- GGG CAG TCG CTT CCA ACG GT-3'), bla $a_{\text {IMP }}$ geni varlığı için F (5'- GGA ATA GAG TGG CTT AAT TCT C-3') R (5' - CCA AAC CAC TAC GTT ATC-3'), bla CGC ATA TCG C-3') R (5'- CGC AGC ACC AGG ATA GAA G-3'), bla KPC geni varlığı için F (5' - ATG TCA CTG TAT CGC CGT C-3') R (5'- TTT TCA GAG CCT TAC TGC CC-3') primerleri kullanıldı ${ }^{8-15}$. Fenotipik olarak kolistine dirençli bulunan izolatlarda $\operatorname{mcr} 1,2,3,4,5,6,7,8$ genleri kolistin direnci gerçek zamanlı PCR kiti (Bio-Speedy, Türkiye) ile araştırıldı.

\section{BULGULAR}

Türkiye'nin 26 düzey-II istatistiki bölgesinden 28 hastane seçilmiş ancak Şanlıurfa Alt Bölgesi (TRC2) ve Ağrı Alt Bölgesi (TRA2)'ne ait hastaneler veri/izolat göndermediği için 26 hastaneden toplanan veriler değerlendirilmiştir. Gönderilen toplam 509 izolatın MALDI TOF MS ile yapılan değerlendirmesinde 493 izolat E.coli ve K.pneumoniae olarak tanımlanmıştır. Değerlendirmeye alınan toplam 493 örneğin \%25.7 ( $\mathrm{n}=127)$ 'si E.coli, \%74.3 $(\mathrm{n}=366)^{\prime} \mathrm{ü}$ K.pneumoniae olup; izolatların \%25.5 ( $\left.\mathrm{n}=126\right)^{\prime} \mathrm{i}$ ayaktan, \%74.5 ( $\left.\mathrm{n}=367\right)^{\prime} \mathrm{i}$ yatan hastalardan izole edilmiştir. E.coli veya K.pneumoniae türleri dışında tanımlanan 16 izolat (Klebsiella oxytoca, $\mathrm{n}=12$; Enterobacter cloacae, $\mathrm{n}=3$; ve Acinetobacter baumannii, $\mathrm{n}=1$ ) çalışma dışı bırakılmış ve değerlendirme dışı bırakılan izolatlar hakkında hastanelere geri bilgilendirme yapılmıştır. Epidemiyolojik verilere göre izolatların \%31 ( $n=153)^{\prime} i$ toplum kökenli, \%69 ( $n=340)^{\prime}$ u sağlık hizmeti ile ilişkili olarak belirlenmiştir, ayrıca izolatların \%6. ( $n=30)^{\prime}$ i kolonizasyon, \%93.9 ( $\left.n=463\right)^{\prime}$ u enfeksiyon etkeni olarak değerlendirilmiştir. Bakterilerin izole edildiği klinik örnekler Şekil 1'de sunulmuştur. İzolatların \%44.1 $(n=217)^{\prime} i$ dahili, \%32.8 ( $\left.n=162\right)^{\prime} i$ yoğun bakım üniteleri ve \%23.1 ( $\left.n=114\right)^{\prime} i$ cerrahi kliniklerde yatan hastalardan izole edilmiştir. Sadece dört hastanın başka bir hastaneden ve bunlardan da sadece birinin şehir dışından transfer olduğu belirlenmiştir. Hiçbir hastanın son altı ayda başka bir ülkeye seyahati bulunmamaktadır. Karbapeneme duyarlı ve dirençli izolatların enfeksiyon kaynağına göre dağılımı ise Şekil 2'de verilmiştir.

Türlere göre antibiyotik duyarlılık sonuçları Tablo III'te verilmiştir. En az bir karbapeneme dirençli olan izolatların farklı antibiyotiklere direnç oranları ise Şekil 3'te gösterilmiştir. Şekil 3'te yer almayan antibiyotiklerin iki tür için de direnç oranları \%95'den fazla olduğu için paylaşıımamıştır. Antibiyotik duyarlılık testleri sıvı mikrodilüsyon yöntemi ile gerçekleştiri- 


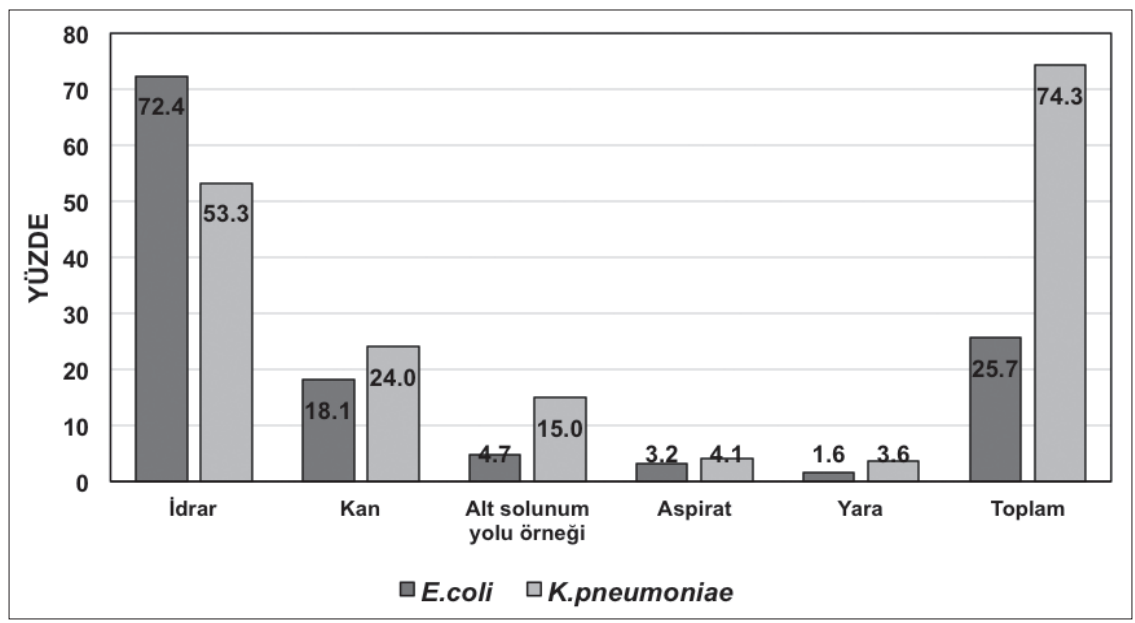

Şekil 1. Izolatların klinik örnek türüne göre dağılımı.

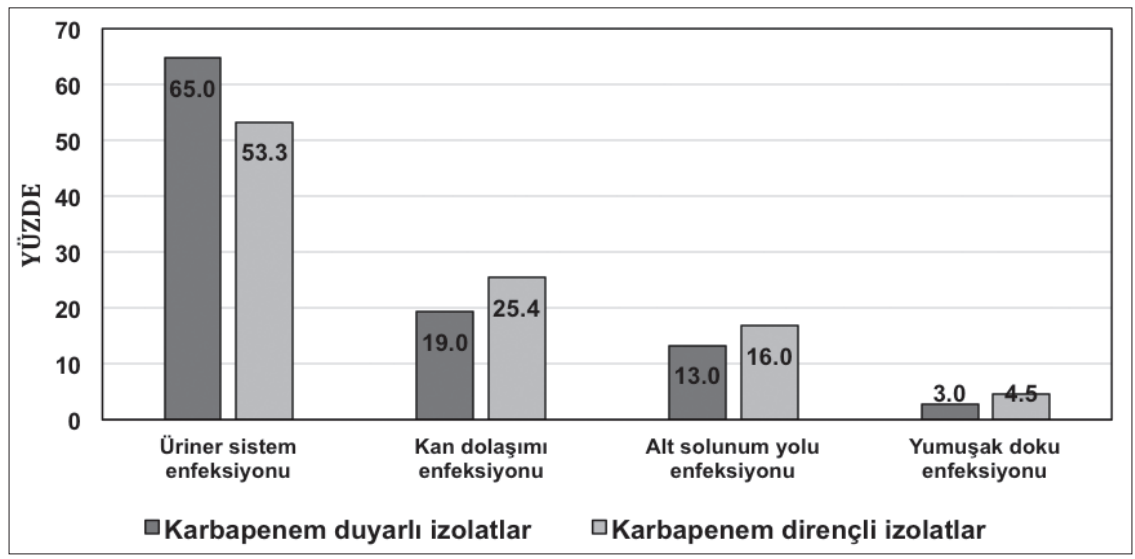

Şekil 2. Karbapeneme duyarlı ve dirençli izolatların izole edildiği enfeksiyon kaynağına göre dağılımı.

len imipenem ve meropenem için dirençli klinik sınır değeri sırasıyla, $>4 \mathrm{mg} / \mathrm{L}$ ve $>8 \mathrm{mg} / \mathrm{L}$ olarak alınmıştır ${ }^{7}$. Hastanelerden karbapeneme duyarlı olarak gönderilen izolatların tümü karbapenemlere duyarlı, dirençli olarak gönderilen izolatların tümü en az bir karbapeneme dirençli bulunmuştur. Katılımcı hastanelere konu ile ilgili bilgilendirme yapılmıştır. Sıvı mikrodilüsyon MiK dağılımları Şekil 4 (K.pneumoniae) ve Şekil 5 (E.coli)'te gösterilmiştir.

Değerlendirmeye alınan izolatlarda test edilen karbapenemlerden yalnız birine direnç, her üç karbapeneme de direnç ve kolistine direnç oranları Tablo IV'te verilmiştir. Hiçbir izolatta mor geni tespit edilmemiştir.

İzolatların \%49.7'si ertapeneme, \%43'ü meropeneme ve \%40.6'sı imipeneme dirençli bulunmuştur. İmipenem ve meropeneme dirençli izolatların tümünün en az bir karbape- 


\begin{tabular}{|c|c|c|c|c|}
\hline Antibiyotik & Bakteriler & Duyarlı, standart doz & Duyarlı, yüksek doz & Dirençli \\
\hline \multirow[t]{3}{*}{ AK } & E.coli & $104(81.9)$ & $4(3.1)$ & $19(15)$ \\
\hline & K.pneumoniae & $230(62.8)$ & $13(3.6)$ & $123(33.6)$ \\
\hline & Toplam & $334(67.7)$ & $17(3.4)$ & $142(28.8)$ \\
\hline \multirow[t]{3}{*}{ AMC } & E.coli & $61(48.1)$ & & $66(51.9)$ \\
\hline & K.pneumoniae & $100(27.3)$ & & $266(72.7)$ \\
\hline & Toplam & $161(32.7)$ & & $332(67.3)$ \\
\hline \multirow[t]{3}{*}{ AM } & E.coli & $27(21.3)$ & & $100(78.7)$ \\
\hline & K.pneumoniae & $\mathrm{UD}^{*}$ & & UD \\
\hline & Toplam (Sadece E.coli) & $27(21.3)$ & & $100(78.7)$ \\
\hline \multirow[t]{3}{*}{ AZT } & E.coli & $59(46.5)$ & $8(6.3)$ & $60(47.2)$ \\
\hline & K.pneumoniae & $96(26.2)$ & $5(1.4)$ & $265(72.4)$ \\
\hline & Toplam & $155(31.4)$ & $13(2.6)$ & $325(65.9)$ \\
\hline \multirow[t]{3}{*}{ FEP } & E.coli & $61(48)$ & $2(1.6)$ & $64(50.4)$ \\
\hline & K.pneumoniae & $99(27)$ & $1(0.3)$ & $266(72.7)$ \\
\hline & Toplam & $160(32.5)$ & $3(0.6)$ & $330(66.9)$ \\
\hline \multirow[t]{3}{*}{ CTX } & E.coli & $52(40.9)$ & & $75(59.1)$ \\
\hline & K.pneumoniae & $89(24.3)$ & $1(0.3)$ & $276(75.4)$ \\
\hline & Toplam & $141(28.6)$ & $1(0.2)$ & $351(71.2)$ \\
\hline \multirow[t]{3}{*}{ CAZ } & E.coli & $56(44.1)$ & $5(3.9)$ & $66(52)$ \\
\hline & K.pneumoniae & $87(23.8)$ & $4(1.1)$ & $275(75.1)$ \\
\hline & Toplam & $143(29)$ & $9(1.8)$ & $341(69.2)$ \\
\hline \multirow[t]{3}{*}{ CIP } & E.coli & $57(44.9)$ & $4(3.1)$ & $66(52)$ \\
\hline & K.pneumoniae & $106(29)$ & $20(5.5)$ & $240(65.6)$ \\
\hline & Toplam & $163(33.1)$ & $24(4.9)$ & $306(62.1)$ \\
\hline \multirow[t]{3}{*}{$\mathrm{COL}$} & E.coli & $116(91.3)$ & & $11(8.7)$ \\
\hline & K.pneumoniae & 262 (71.6) & & $104(28.4)$ \\
\hline & Toplam & $378(76.7)$ & & $115(23.3)$ \\
\hline \multirow[t]{3}{*}{ ERT } & E.coli & $95(74.8)$ & & $32(25.2)$ \\
\hline & K.pneumoniae & $153(41.8)$ & & $213(58.2)$ \\
\hline & Toplam & $248(50.3)$ & & $245(49.7)$ \\
\hline \multirow[t]{3}{*}{$\mathrm{CN}$} & E.coli & $91(71.7)$ & & $36(28.3)$ \\
\hline & K.pneumoniae & $210(57.4)$ & & $156(42.6)$ \\
\hline & Toplam & $301(61.1)$ & & $192(38.9)$ \\
\hline \multirow[t]{3}{*}{ IMP } & E.coli & $101(79.5)$ & $4(3.1)$ & $22(17.3)$ \\
\hline & K.pneumoniae & $180(49.2)$ & $8(2.2)$ & $178(48.6)$ \\
\hline & Toplam & $281(57)$ & $12(2.4)$ & $200(40.6)$ \\
\hline
\end{tabular}




\begin{tabular}{|c|c|c|c|c|}
\hline Antibiyotik & Bakteriler & Duyarli, standart doz & Duyarlı, yüksek doz & Dirençli \\
\hline \multirow[t]{3}{*}{ MEM } & E.coli & $103(81.1)$ & $2(1.6)$ & $22(17.3)$ \\
\hline & K.pneumoniae & $175(47.8)$ & $1(0.3)$ & $190(51.9)$ \\
\hline & Toplam & $278(56.4)$ & $3(0.6)$ & $212(43)$ \\
\hline \multirow[t]{3}{*}{ TZP } & E.coli & $74(58.3)$ & $4(3.1)$ & $49(38.6)$ \\
\hline & K.pneumoniae & $117(32)$ & $19(5.2)$ & $230(62.8)$ \\
\hline & Toplam & $191(38.7)$ & $23(4.7)$ & $279(56.6)$ \\
\hline \multirow[t]{3}{*}{ ТОВ } & E.coli & $72(56.7)$ & $1(0.8)$ & $54(42.5)$ \\
\hline & K.pneumoniae & 145 (39.6) & $3(0.8)$ & $218(59.6)$ \\
\hline & Toplam & $217(44)$ & $4(0.8)$ & $272(55.2)$ \\
\hline \multirow[t]{3}{*}{ TMP-SXT } & E.coli & $55(43.3)$ & & $72(56.7)$ \\
\hline & K.pneumoniae & $102(27.9)$ & & $264(72.1)$ \\
\hline & Toplam & $157(31.8)$ & & $336(68.2)$ \\
\hline \multicolumn{5}{|c|}{$\begin{array}{l}\text { AK: Amikasin, AMC: Amoksisilin-klavulonik asit, AM: Ampisilin, AZT: Aztreonam, FEP: Sefepim, CTX: Sefotaksim, } \\
\text { CAZ: Seftazidim, CIP: Siprofloksasin, COL: Kolistin, ERT: Ertapenem, CN: Gentamisin, IMP: İmipenem, MEM: } \\
\text { Meropenem, TZP: Piperasilin tazobaktam, TOB: Tobramisin, TMP-SXT: trimetoprim sülfametoksazol } \\
\text { *UD: Uygun değil. }\end{array}$} \\
\hline
\end{tabular}

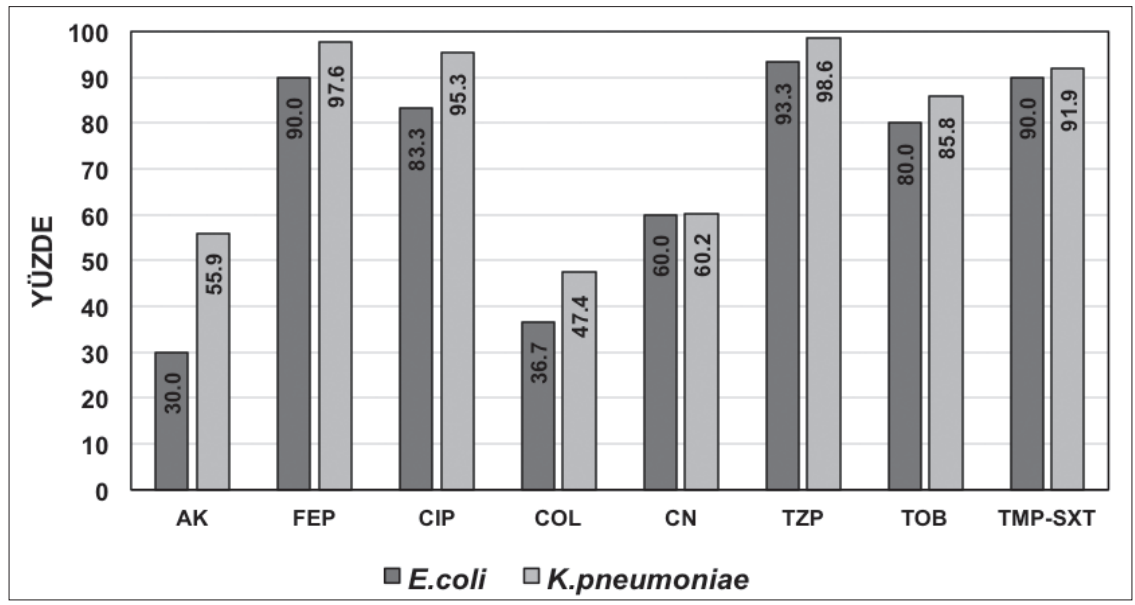

Şekil 3. Karbapenem dirençli izolatların farklı antibiyotiklere karşı direnç yüzdeleri.

AK: Amikasin, FEP: Sefepim, CIP: Siprofloksasin, COL: Kolistin, CN: Gentamisin, TZP: Piperasilin tazobaktam, TOB: Tobramisin, TMP-SXT: Trimetoprim sülfametoksazol.

nemaz direnç genine sahip olduğu genotipik olarak belirlenmiş̧ir. ancak fenotipik olarak ertapeneme dirençli 38 izolatta ise bakılan direnç genlerinden herhangi biri belirlenememiştir. Genotipik olarak toplam 207 izolatın karbapenemaz direnç genine sahip olduğu tespit edilmiş̧ir. Tek tip karbapenemaz geni pozitifliği saptanan izolatların oranları sirasiyla, OXA-48: \%52.2 ( $n=108) ;$ KPC: \%16.4 ( $n=34)$; NDM-1: \%15 ( $n=31)$ ve VIM: $\% 0.5(n=1)$ olarak bulunmuşken iki gen pozitifliği saptanan izolatların oranları sırasıyla, 


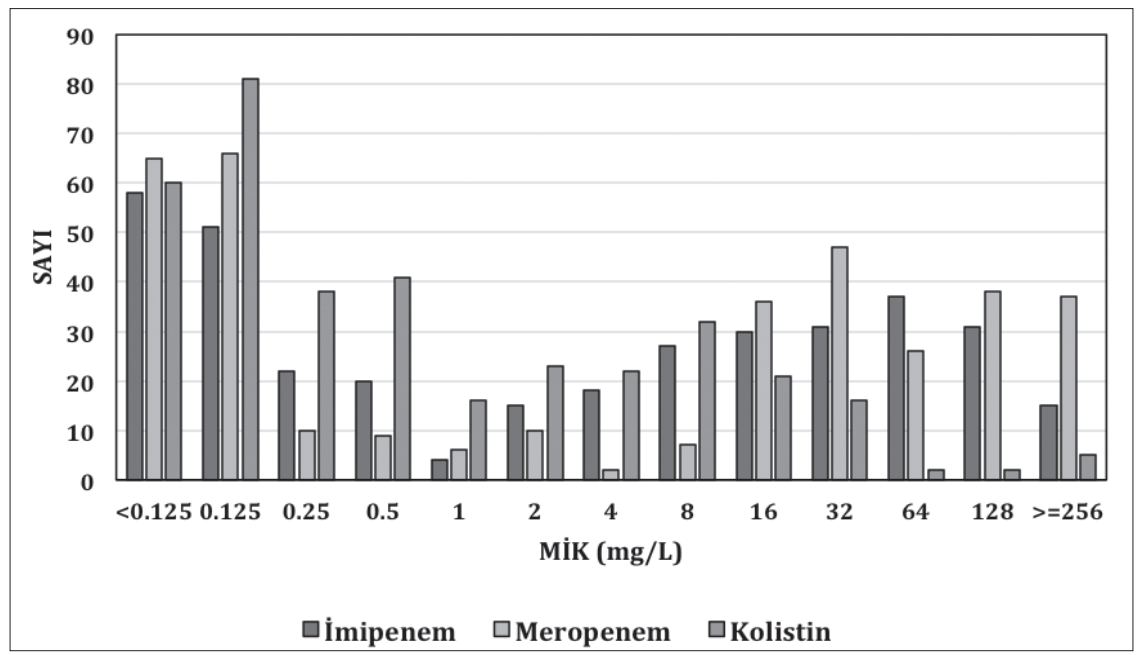

Şekil 4. K.pneumoniae izolatlarının sıvı mikrodilüsyon ile çalısıllan antibiyotiklerin Mik dağılımları.

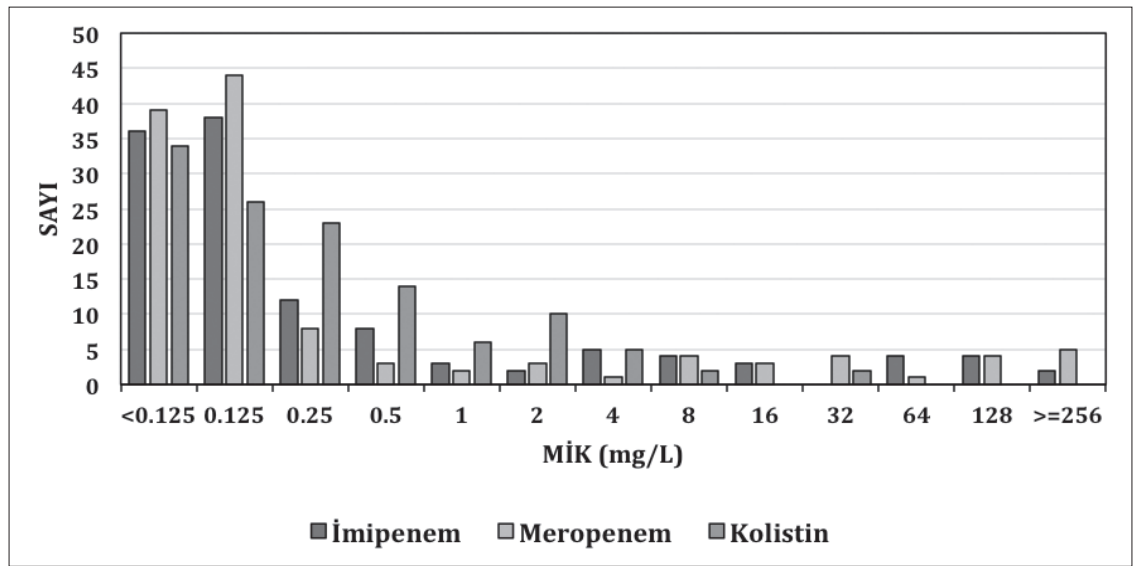

Şekil 5. E.coli izolatlarının sıvı mikrodilüsyon ile çalışılan antibiyotiklerin Mik dağılımları.

\begin{tabular}{lcccccc}
\hline \multicolumn{7}{l}{ Tablo IV. Karbapenem ve Kolistine Dirençli Izolatların Dağılımı } \\
\cline { 2 - 7 } & \multicolumn{7}{c}{ Karbapenem } & $\begin{array}{c}\text { Herhangi Bir } \\
\text { Karbapeneme } \\
\text { Bakteri }\end{array}$ & $\begin{array}{c}\text { Karbapeneme } \\
\text { Dirençli }\end{array}$ & Dirençli & Duyarlı & Dirençli & \\
\hline E.coli & $97(76.4)$ & $30(23.6)$ & $19(15.0)$ & $116(91.3)$ & $11(8.7)$ & 127 \\
K.pneumoniae & $151(41.3)$ & $215(58.7)$ & $174(47.5)$ & $262(71.6)$ & $104(28.4)$ & 366 \\
Toplam & $248(50.3)$ & $245(49.7)$ & $193(39.1)$ & $378(76.7)$ & $115(23.3)$ & 493 \\
\hline
\end{tabular}




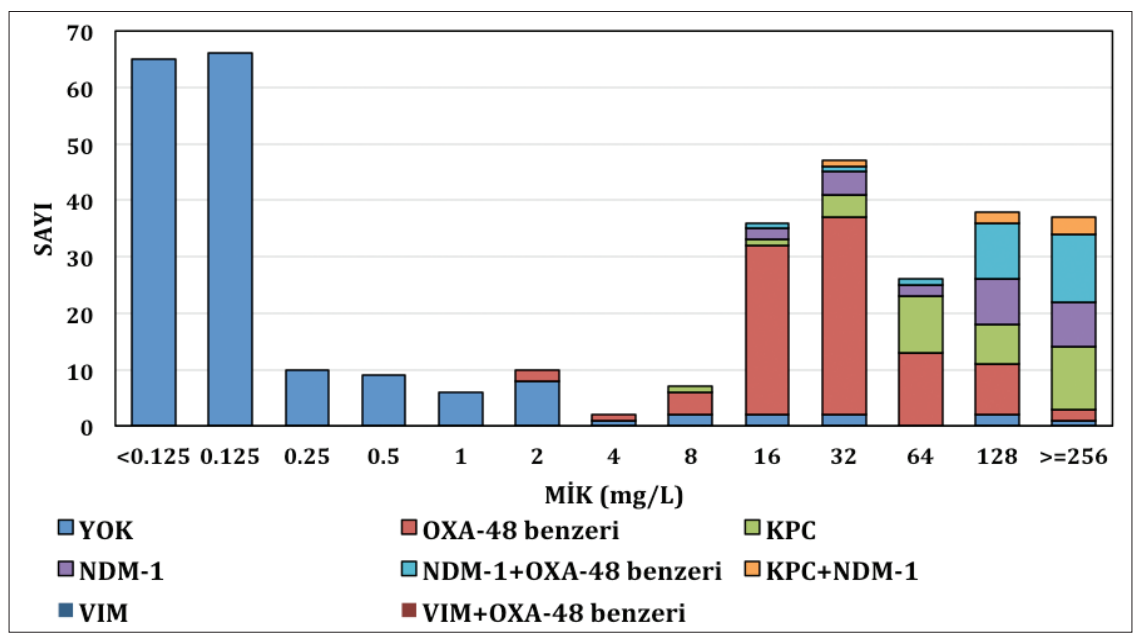

Şekil 6. K.pneumoniae izolatlarının meropenem Mik dağılımlarına göre karbapenemaz enzim tipinin dağılımı.

OXA-48 + NDM-1: \%12.6 $(n=26) ;$ KPC + NDM-1: \%2.8 $(n=6)$ ve OXA-48 + VIM: \%0.5 $(n=1)$ olarak tespit edilmiştir. İzolatların meropenem MiK dağılımlarına göre karbapenemaz tipleri Şekil 6'da verilmiştir.

\section{TARTIŞMA}

Küresel ya da bölgesel epidemiyolojik verinin sağlanması dünya çapında önemli bir sorun olan antibiyotik direncinin önlenmesinde ve sürecin yönetiminde katkı sağlayacak bir unsurdur. Bu nedenle antibiyotik direncinde ulusal sürveyansın yanı sıra bölgesel ya da küresel veri sağlanmasına yönelik dünya genelinde birçok çalışma yürütülmektedir ${ }^{4}$. Sürveyans sistemlerinde amaç hem standardize hem de kıyaslanabilen güvenilir verinin sağlanmasıdır ${ }^{5}$. Günümüzde sadece direncin değil direnç genlerinin epidemiyolojisinin de ortaya konması ve izlenmesi antibiyotik direncinin yönetimindeki önemli kilometre taşlarından biri haline gelmiştir. Bu çalışmada ECDC önderliğinde Avrupa kıtasındaki 37 ülkeyi içine alacak şekilde kurulan EURGen-Net sürveyans sistemi kapsamında Türkiye'de toplanan izolatların değerlendirme sonuçları yer almaktadır.

Türkiye'nin 26 farklı istatistiki düzey-II bölgesinden seçilen 28 hastaneden Şanlıurfa Alt Bölgesi (TRC2) ve Ağrı Alt Bölgesi (TRA2)ne ait hastaneler veri/izolat göndermediği için 26 hastanenin 509 izolatı değerlendirmeye alınmış ancak bu izolatlardan MALDI TOF MS ile yapılan tanımlamada toplam 493 izolat E.coli veya K.pneumoniae olarak tür düzeyinde tanımlanarak çalışmaya dahil edilmiştir. Diğer 16 izolat katılımcı hastanelerden farklı tanımlandığı için değerlendirmeye alınmamıştır. Tanımlamada belirlenen farklııklar ve çalışmaya dahil edilmeyen izolat sayısı hastanelere bildirilmiştir.

İzolatların toplandığı kişilere ait klinik ve epidemiyolojik veriler değerlendirildiğinde; izolatların \%69'unun sağlık hizmetleri ile ilişkili enfeksiyonlardan elde edildiği görülmüştür. Karbapenem ve/veya kolistin dirençli izolatların neredeyse tümünün sağlık hizmetleri 
ile ilişkili enfeksiyonlardan izole edildikleri göz önüne alındığında bu durumun beklentiler ile uyumlu olduğu değerlendirilmiştir. İzolatların sadece \%6.1'inin kolonize olduğu tespit edilmiştir. Çalışmaya dahil edilen hastaların hiçbirinin başka bir ülkeye seyahati olmamakla birlikte sadece bir hasta farklı bir şehirdeki hastaneden transfer edilmiştir. Özellikle NDM-1 geninin yayılım özelliklerini tanımlayan çalışmaların bulguları ülkeler ve hatta kıtalar arasındaki seyahat öykülerinin direncin yayılmasındaki önemini ortaya koymaktadır $^{15}$. Bu nedenle antibiyotik direncinin kaynağının araştırılmasında artık yaygın olarak başka bir ülkeden seyahat öyküsü olup olmadığı sorgulanmaktadır.

Bakterilerin izole edildiği klinik örnek açısından bakıldığında idrar ve kan kültüründen elde edilen izolatların diğer klinik örneklere göre daha fazla olduğu buna bağlı olarak enfeksiyonların da en sık üriner sistem ve kan dolaşımı enfeksiyonlarına bağlı olduğu görülmektedir. Ülkemizde mikrobiyoloji laboratuvarlarına gönderilen idrar örnek sayılarının diğer klinik örneklere göre daha fazla olmasının bu durum üzerinde de etkili olduğu düşünülmüştür.

Ülkemizde 2011 ve 2018 yılları arasında karbapenemaz üreten Enterobacterales türlerinin dağılımları "hastane içi salgınlar" kategorisinden ülkedeki birçok hastanede salgınlara neden olan "endemik" duruma geçmiştir. Avrupa Bölgesinde Türkiye dışında 2018 yılında karbapenemaz üreten Enterobacterales izolatlarının endemik olduğu diğer ülkelerin ise Yunanistan, İtalya ve Malta olduğu bildirilmiştir ${ }^{16}$.

Ülkemizin karbapenemaz epidemiyolojisi açısından değerlendirmesi yapıldığında 2001 yılında K.pneumoniae' da ilk defa OXA-48 geni tespit edilmiş ve bunu takiben beş yıl sonra OXA-48 pozitif K.pneumoniae hastane salgınları görülmüştür ${ }^{9,17-18}$. Salgınlar ile birlikte NDM-1 geni pozitif izolatlar ile OXA-48 ve NDM-1 birlikte pozitifliği gösteren izolatlar ortaya çıkmıştı ${ }^{19,20}$. Türkiye'de KPC geni üreten izolatların varlığı sporadik olarak 2018 yılına ait izolatlarda tespit edilmiştir ${ }^{21}$. Ülkemizde 2013 yılına ait izolatların dahil edildiği European Survey on Carbapenemase Producing Enterobacteriaceae (EuSCAPE) projesinde de benzer bir metodoloji ile ülkenin farklı bölgelerinden toplanan E.coli ve K.pneumoniae izolatlarının karbapenemaz enzim tipleri araştırılmıştır. Çalışmada 143 izolatta genotipik olarak en az bir karbapenemaz enzimi tespit edilmiştir. Tek tip karbapenemaz enzim oranları sırasıyla OXA-48 (\%84.6). NDM-1 (\%6.3). VIM (\%2.8). IMP (\%1.4) bulunurken. yedi izolatta ise iki enzim bir arada (OXA-48+NDM-1 (\%2.1). OXA-48+VIM (\%2.1). VIM+NDM-1 $(\% 0.7))$ tespit edilmiştir. Bu çalışma ile kıyaslandığında OXA-48'in halen ülkemizde görülen baskın karbapenemaz enzimi olmasına karşın, metalo-beta-laktamaz tiplerinde özellikle NDM-1'de artış olduğunu söylemek mümkündür. KPC tipi karbapenemaz enzimi ise, 2013 yılına ait izolatlarda hiç tespit edilememiş olmasına rağmen 2019 yılına ait izolatlarda KPC izolatlarının metalo-beta-laktamazlar kadar yaygınlaştığı söylenebilir ${ }^{22}$.

Ülkemizde yaşadığımız bu sürecin tam tersi durumu Portekiz'de gözlenmektedir. Portekiz'de KPC tipi beta-laktamaz endemik olmasına rağmen, son yıllarda OXA-48'in yayılmaya başladığı belirlenmiştir ${ }^{23}$. Karbapenemaz epidemiyolojisinin ulusal ve bölgesel bazda değişmesinden dolayı belirli aralıklarla sağlanan verilerin bölgesel olarak paylaşılmasının antibiyotik direncinin yönetimine olumlu katkı sağlayacağı düşünülmektedir. 
Günümüzde karbapenem dirençli Enterobacterales türlerinin yayılımı tüm dünyada gözlenmektedir ve karbapenemaz türleri bölgeler arasında farklılıklar göstermektedir. Halk sağlığını tehdit eden bu izolatların moleküler karakterizasyonu, epidemiyolojik çaış̧maları ve sürveyans ile izlenmeleri erken dönemde doğru tedavi yaklaşımlarına olanak sağlamasının yanında proaktif bir yaklaşımla hızlı yayılımlarının da kontrol altına alınmasını sağlayacaktır ${ }^{24}$. Dünya genelinde karbapenemaz türleri içinde en sık KPC endemik özelliğindedir ve endemisite en sık Amerika Birleşik Devletleri, İsrail, Latin Amerika ve Yunanistan'da görülmektedir ${ }^{24}$. Karbapenemaz türlerinin belirlenmesi ile tedavi seçeneklerine karar verilme ve tedavi sürecinin yönetilmesine önemli katkı sağlanabilir ${ }^{25}$. Örneğin, seftazidim-avibaktamın özellikle KPC ve OXA-48 pozitif izolatlar üzerinde etkinliğinin yaklaşık \%98 olduğu bildirilmesine karşın, VIM ve NDM-1 gibi B sınıfı karbapenemazlar üzerinde etkinliği bulunmamaktadır ${ }^{26}$. Çalışma verilerimiz karbapenem Mik değeri ile karbapenemaz türü arasında ilişki olduğunu göstermektedir. Özellikle KPC ve NDM enzim tipinde Mik değerlerinin daha yüksek olduğu belirlenmiştir.

İzolatların diğer antibiyotiklere olan duyarlılıkları incelendiğinde özellikle karbapenemlere dirençli izolatlarda direnç oranlarının yüksek olduğu amikasin ve gentamisine olan duyarlılık oranlarının ise değerlendirilen diğer antibiyotiklere göre daha yüksek olduğu gözlenmiştir. Çalışma kapsamında kolistine direnç oranı \%23.3 olarak belirlenmiştir. Sıvı mikrodilüsyon testi ile dirençli bulunan izolatlarda $m c r 1-8$ ve alt varyantlarının çalışıldığı bu izolatlarda mcr tiplerinin hiçbiri tespit edilememiştir. Ülkemizden yapılan iki çalışmada. klinik örneklerden toplam üç izolatta $m c r-1$ pozitifliği belirlenmiş̧ir ${ }^{27,28}$. Ülkemizde kolistin dirençli izolatlarda $\mathrm{mcr}$ dışı mekanizmaların da araştııılması gerekmektedir.

Çalışmada iki hastanenin veri ve izolat göndermemesinden dolayı iki bölgeden herhangi bir veri toplanamamıştır. Bu nedenle ülke genelinin temsil edilebilirliği azalmıştır. Ayrıca bölgelerden tek hastaneden veri toplandığından bölgesel bir dağılım için bir değerlendirme yapmak da mümkün olmamıştır. Illerleyen yıllarda bölgedeki hastane sayısı arttırılarak bölgesel verinin sağlanması da mümkün olacaktır. Bu çalışmanın bir diğer kısıtlılığı ise kolonizasyon olarak belirlenen izolatların çalışmaya dahil edilmesidir. Bu izolatların verilerin doğruluğu üzerinde olumsuz bir etkiye sahip olacağını düşünmekle beraber çalışma protokolü EURGen-NET protokolüne bağlı olduğu için kolonizasyona neden olan izolatlar analizden dışlanmamıştır.

Ülkemizde moleküler bazlı karbapenemaz sürveyansının sürekliliğinin sağlanması ve ülke genelinde yaygınlaştırılmasının karbapenemaz epidemiyolojisinin izlemi, kaliteli verinin sağlanması ve laboratuvar kapasitesinin arttırılması yönünde önemli olacağını düşünüyoruz.

\section{ETIK KURUL ONAYI}

Bu çalışma, T.C. Sağlık Bakanlığı Halk Sağlığı Genel Müdürlüğünün onayı ile gerçekleştirildi (Tarih: 08.10.2020 ve Karar no: 80962070). 


\title{
ÇIKAR ÇATIŞMASI
}

\begin{abstract}
Yazarlar bu makale ile ilgili herhangi bir çıkar çatışması bildirmemişlerdir.
* Ulusal Karbapenemaz Sürveyans Çalışma Grubu (İsme göre alfabetik olarak sıralanmıştır.) Alper Akçalı (On Sekiz Mart Üniversitesi Tıp Fakültesi, Tıbbi Mikrobiyoloji Anabilim Dalı, Çanakkale), Ayșe Ulusoy Karaca (Bursa Şevket Yılmaz Eğitim ve Araștırma Hastanesi, Mikrobiyoloji Laboratuvarı, Bursa), Banu Bayraktar (Şişli Hamidiye Etfal Eğitim ve Araştırma Hastanesi, Mikrobiyoloji Laboratuvarı, İstanbul), Canan Eryıldız (Trakya Üniversitesi Tıp Fakültesi Hastanesi, Tıbbi Mikrobiyoloji Anabilim Dalı, Edirne), Cem Çelik (Cumhuriyet Üniversitesi Tıp Fakültesi, Tıbbi Mikrobiyoloji Anabilim Dalı, Sivas), Devrim Dündar (Kocaeli Üniversitesi Tıp Fakültesi Araştırma ve Uygulama Hastanesi, Tıbbi Mikrobiyoloji Anabilim Dalı, Kocaeli), Ebru Evren (Ankara Üniversitesi Tıp Fakültesi, İbn-i Sina Hastanesi, Tıbbi Mikrobiyoloji Anabilim Dalı, Ankara), Eda Demirkan (Erzurum Bölge Eğitim ve Araştırma Hastanesi, Mikrobiyoloji Laboratuvarı, Erzurum), Esra Özkaya (Karadeniz Teknik Üniversitesi Tıp Fakültesi, Tıbbi Mikrobiyoloji Anabilim Dalı, Trabzon), Fatma Bağcı (Hatay Antakya Devlet Hastanesi, Mikrobiyoloji Laboratuvarı, Hatay), Fikriye Milleti Sezgin (Ahi Evran Üniversitesi Kırşehir Eğitim ve Araştırma Hastanesi, Mikrobiyoloji Laboratuvarı, Kırşehir), Filiz Kibar (Çukurova Üniversitesi Tıp Fakültesi, Balcalı Hastanesi, Tıbbi Mikrobiyoloji Anabilim Dalı, Adana), Hatice Türk Dağı (Selçuk Üniversitesi Tıp Fakültesi, Tıbbi Mikrobiyoloji Anabilim Dalı, Konya), Hüseyin Güdücüoğlu (Van Yüzüncü Yıl Üniversitesi Tıp Fakültesi, Tıbbi Mikrobiyoloji Anabilim Dalı, Van), İpek Mumcuoğlu (Bilkent Şehir Hastanesi, Mikrobiyoloji Laboratuvarı, Ankara), Mahmut Celalettin Üner (Mardin Devlet Hastanesi, Mikrobiyoloji Laboratuvarı, Mardin), Melahat Gürbüz (Kastamonu Münif İslamoğlu Devlet Hastanesi, Mikrobiyoloji Laboratuvarı, Kastamonu), Murat Telli (Adnan Menderes Üniversitesi Tıp Fakültesi, Tıbbi Mikrobiyoloji Anabilim Dalı, Aydın), Mustafa Zahir Bakıcı (Cumhuriyet Üniversitesi Tıp Fakültesi, Tıbbi Mikrobiyoloji Anabilim Dalı, Sivas), Nergis Aşgın (Karabük Eğitim ve Araştırma Hastanesi, Mikrobiyoloji Laboratuvarı, Karabük), Osman Sezer Cirit (Gaziantep Ersin Arslan Eğitim ve Araştırma Hastanesi, Mikrobiyoloji Laboratuvarı, Gaziantep), Pervin Özlem Balı (Tokat Devlet Hastanesi, Mikrobiyoloji Laboratuvarı, Tokat), Rıza Adaleti (Haydarpaşa Numune Eğitim ve Araștırma Hastanesi, Mikrobiyoloji Laboratuvarı, i̇stanbul), Sebahat Aksaray (Haydarpaşa Numune Eğitim ve Araștırma Hastanesi, Mikrobiyoloji Laboratuvarı, ìstanbul), Senem Akgül (Manisa Devlet Hastanesi, Mikrobiyoloji Laboratuvarı, Manisa), Şöhret Aydemir (Ege Üniversitesi Tıp Fakültesi, Tıbbi Mikrobiyoloji Anabilim Dalı, İzmir), Yeșim Çekin (Antalya Eğitim ve Araştırma Hastanesi, Mikrobiyoloji Laboratuvarı, Antalya), Yücel Duman (İnönü Üniversitesi Tıp Fakültesi Turgut Özal Tıp Merkezi Hastanesi, Tıbbi Mikrobiyoloji Anabilim Dalı, Malatya), Zeynep Ceren Karahan (Ankara Üniversitesi Tıp Fakültesi, ibn-i Sina Hastanesi, Tıbbi Mikrobiyoloji Anabilim Dalı, Ankara)
\end{abstract}

\section{KAYNAKLAR}

1. World Health Organization (WHO). Antimicrobial resistance: global report on surveillance. WHO 2014. Accessed from: https://www.who.int/drugresistance/documents/surveillancereport/en/

2. van Duin D, Paterson DL, Multidrug-resistant bacteria in the community: Trends and lessons learned. Infect Dis Clin North Am 2016; 30: 377-90.

3. van Duin D, Doi Y. The global epidemiology of carbapenemase-producing Enterobacteriaceae. Virulence 2017; 8(4): 460-9.

4. World Health Organization (WHO). Global antimicrobial resistance surveillance system (GLASS) report. Early implementation 2017-2018. WHO 2018.

5. Süzük Yıldız S, Şimşek H, Çöplü N, Gülay Z, UAMDS Study Group. National Antimicrobial Resistance Surveillance System (NAMRSS) external quality assessment studies: 2011-2016. Mikrobiyol Bul 2017; 51(3): 247-59.

6. ECDC study protocol for genomic-based surveillance of carbapenem resistant and/or colistin-resistant Enterobacteriaceae at the EU level-Version 2.0-EN. 2018.

7. European Committee on Antimicrobial Susceptibility Testing (EUCAST). Breakpoint tables for interpretation of MICs and zone diameters. Version 9.0.2019.

8. Hou C, Yang F. Drug-resistant gene of blaOXA-23. blaOXA-24. blaOXA-51 and blaOXA-58 in Acinetobacter baumannii. Int Clin Exp Med 2015; 8: 13859-63.

9. Poirel L, Bonnin RA, Nordmann P. Genetic features of the widespread plasmid coding for the carbapenemase OXA-48. Antimicrob Agents Chemother 2012; 56: 559-62.

10. Zhou H, Pi BR, Yang Q, Yu YS, Chen YG, Li LJ, et al. Dissemination of imipenem-resistant Acinetobacter baumannii strains carrying the ISAba1 blaOXA-23 genes in a Chinese hospital. J Med Microbiol 2007; 56(8): 1076-80.

11. Mushtaq S, Irfan S, Sarma JB, Pike R, Pitout J, Livermore DM, et al. Phylogenetic diversity of Escherichia coli strains producing NDM-1-type carbapenemases. J Antimicrob Chemother 2011; 66: 2002-5.

12. Garza-Ramos U, Morfin Otero R, Sader HS, Jones RN, Harmandez E, Rodriguez Noriega E, et al. Metallo-betalactamase gene bla (IMP-15) in a class 1 integron. In95. from Pseudomonas aeruginosa clinical isolates from a hospital in Mexico. Antimicrob Agents Chemother 2008; 52: 2943-6.

13. Gomez-Gil MR, Pano-Pardo JR, Romeo Gomez MP, Gasior M, Lorenzo M, Quiles I, et al. Detection of KPC-2producing Citrobacter freundii isolates in Spain. J Antimicrob Chemother 2010; 65: 2695-7. 
14. Kaczmarek FM, Dib-Hajj F, Shang W, Gootz TD. High-level carbapenem resistance in a Klebsiella pneumoniae clinical isolate is due to the combination of bla(ACT-1) beta-lactamase production. porin OmpK35/36 insertional inactivation and downregulation of the phosphate transport porin PhoE. Antimicrob Agents Chemother 2006; 50: 3396-406.

15. Woodford N, Johnson AP. Global spread of antibiotic resistance: the example of New Delhi metallo- $\beta$ lactamase (NDM-1)-mediated carbapenem resistance. J Med Microbiol 2013; 62(4): 499-513.

16. Brolund A, Lagerqvist N, Byfors S, Struelens MJ, Monnet DL, Albiger B, et al. European Antimicrobial Resistance Genes Surveillance Network (EURGen-Net) capacity survey group. Worsening epidemiological situation of carbapenemase-producing Enterobacteriaceae in Europe. assessment by national experts from 37 countries. July 2018. Euro Surveill 2019; 24(9): 1-8.

17. Carrer A, Poirel L, Eraksoy H, Cagatay AA, Badur S, Nordmann P. Spread of OXA-48-positive carbapenemresistant Klebsiella pneumoniae isolates in Istanbul Turkey. Antimicrob Agents Chemother 2008; 52(8): 2950 4.

18. Cuzon G, Ouanich J, Gondret R, Naas T, Nordmann P. Outbreak of OXA-48-positive carbapenem-resistant Klebsiella pneumoniae isolates in France. Antimicrob Agents Chemother 2011; 55(5): 2420-3.

19. Poirel L, Ozdamar M, Ocampo-Sosa AA, Türkoglu S, Ozer UG, Nordmann P. NDM-1-producing Klebsiella pneumoniae now in Turkey. Antimicrob Agents Chemother 2012; 56(5): 2784-5.

20. Süzük Yıldız S, Kaşkatepe B, Şimşek H, Sarıgüzel FM. High rate of colistin and fosfomycin resistance among carbapenemase-producing Enterobacteriaceae in Turkey. Acta Microbiol Immunol Hung 2019; 66(1): 10312.

21. Tekeli A, Dolapci I, Evren E, Oguzman E, Karahan ZC. Characterization of Klebsiella pneumoniae Coproducing KPC and NDM-1 Carbapenemases from Turkey. Microb Drug Resist 2020; 26(2): 118-25.

22. Çakar A, Akyön Y, Gür D, Karatuna O, Öğünç D, Özhak Baysan B, et al. Türkiye'de 2014 yılı içinde izole edilen karbapeneme dirençli Escherichia coli ve Klebsiella pneumoniae izolatlarında karbapenemaz varlığının araştırılması. Mikrobiyol Bul 2016; 50(1): 21-33.

23. Lopes E, Saavedra MJ, Costa E, de Lencastre H, Poirel L, Aires-de-Sousa M. Epidemiology of carbapenemaseproducing Klebsiella pneumoniae in Northern Portugal: Predominance of KPC-2 and OXA-48. J Glob Antimicrob Resist 2020; 7165(20): 30101-6.

24. Logan LK, Weinstein RA. The epidemiology of carbapenem-resistant Enterobacteriaceae: The impact and evolution of a global menace. J Infect Dis 2017; 215(1): 28-36.

25. Lagacé-Wiens P, Walkty A, Karlowsky JA. Ceftazidime-avibactam: an evidence based review of its pharmacology and potential use in the treatment of Gram negative bacterial infections. Core Evid 2014; 24(9): 13-25.

26. Alexander EL, Loutit J, Tumbarello M, Wudrenik R, Felton T, Daikos G, et al. Carbapenem-resistant Enterobacteriaceae infections: results from a retrospective series and implications for the design of prospective clinical trials. Open Forum Infect Dis 2017; 4:ofx063.

27. Arabacı Ç, Dal T, Başyiğit T, Genişel N, Durmaz R. Investigation of carbapenemase and mcr-1 genes in carbapenem-resistant Klebsiella pneumoniae isolates. J Infect Dev Ctries 2019; 13(6): 504-9.

28. Özkaya E, Buruk CK, Tosun I, Toraman B, Kaklıkkaya N, Aydın F. Investigation of plasmid mediated $m c r$ colistin resistance gene in clinical Enterobacterales Isolates. Mikrobiyol Bul 2020; 54(2): 191-202. 